IFN Working Paper No. 888, 2011

\title{
What Can International Finance Add to International Strategy?
}

Lars Oxelheim, Trond Randøy and Arthur Stonehill 


\title{
What Can International Finance Add to International Strategy? \\ Lars Oxelheim, Trond Randøy and Arthur Stonehill
}

\author{
Forthcoming in Verbeke, A and H. Merchant, Handbook of Research on International Strategic Management, \\ London: Edgar Elgar
}

\begin{abstract}
This chapter focuses on the role of corporate financial strategies to improve firms' market valuations, and thus lower their cost of capital. The identification of successful strategies is accomplished within an overall strategic framework and related to how the firm perceives the degree of international financial integration. Five strategies for how to break out of a segmented, thin domestic capital market are highlighted together with historical success cases. The chapter illustrates the linkages between business strategy, firm motivation, and various financial strategies.
\end{abstract}

JEL: F21, F23, F36, G32, G34.

Key words: Financial strategy, corporate strategy, global competitiveness, cost of capital Acknowledgement: Financial support from the NASDAQ OMX Nordic Foundation is gratefully acknowledged by Lars Oxelheim. 


\section{What Can International Finance Add to International Strategy?}

\section{Introduction}

The 1980s and 1990s offered a remarkable increase in international financial integration of many OECD countries but left many small emerging and developing countries outside this "global" financial market. In the integration process as described in Oxelheim (1996), the Nordic economies were able to foster a remarkable number of high-growth capital intensive companies, such as Nokia from Finland, Ericsson from Sweden, and Novo-Nordisk from Denmark. We argue that without the skillful global financial strategies that enabled these companies to access global savings, the limited domestic availability and high cost of capital would have hampered their growth. We suggest that these company historical accounts provide valuable insight for scholars as well as for executives today, in particular for smaller and medium-sized growth-oriented firms from emerging economies.

In order to succeed in a global financial market, firms' executives must be capable of delivering the strategy story to the stock analysts and, ultimately, share value to the money managers (Useem, 1998). We find Useem's argument being equally true today. The on-going globalization of equity markets provides the firm the opportunity to actively reduce information and agency costs, and hence to contribute to higher firm values by the means of lower cost of capital (Bekaert and Harvey, 2000; Doidge, Karolyi and Stulz, 2004; Hearn, Piesse and Strange, 2010; Mittoo and Zhang, 2008) and better corporate governance (Coffee, 2002; Oxelheim and Randøy, 2003). This is particularly true for emerging markets or thin capital markets (O’Connor, 2011). The rise of global portfolio investment has laid the ground for more emphasis on shareholder relations. The international portfolio managers judge the potential company to invest in against the best-performing firms in each industry and no 
longer against its domestic peers only. For small and medium sized companies in particular, but also for large companies outside the Anglo-American world, and major countries like Japan and Germany, the gain of access to highly liquid and competitively priced capital markets can effectively boost growth.

In the rest of this chapter we will emphasize successful financial strategies for companies from small and/or emerging economies for gaining global investor recognition. The brief story of Nokia's rise to become the global leader in cell phone production may serve as an introduction.

When the fast growing telecommunication company Nokia of Finland needed US\$ 485 million in 1994, access to competitively priced funds was necessary in order to keep pace with competitors. In early 1994 the common stocks of Nokia's major competitors were priced at 22 (Motorola) and 25 (Ericsson) times earnings, however, Nokia was valued at only 14 times earnings. To become more attractive to global investors, the firm listed on the NYSE (New York Stock Exchange) and made a Euro-equity offering. Within three months of NYSE trading Nokia's stock had gained $45 \%$ versus a $2 \%$ gain for the NYSE composite index. Nokia had achieved global recognition among investors, and was now classified and priced as one of the peers in the telecommunication industry. Today the level of market segmentation in relation to a country like Finland - is much smaller - and the costs of NYSE listing has increased significantly - so the net benefits of such listing is now less obvious. Hence, it boils down to a cost-benefit analysis of investing in global recognition. Some of the investments coincide with investing in the build-up of a corporate brand name. Or to put it differently, the financial strategy to internationalize overlaps with the international marketing strategy.

The chapter is organized as follows. In the next section we address increased financial integration and a better access to global savings implying that a Swedish firm may borrow savings from households in Australia to invest in the US. Thereafter we discuss why having a 
financial strategy matters. Then follows a review of barriers to an international cost of capital that have to be circumvented or passed by the firm. We use longitudinal company cases to provide lesson to firms from thin or emerging capital markets of the early 2010s. Then follows a section in which we link the business strategy, financial strategy and corporate performance. The chapter ends with concluding remarks.

\section{On the segmentation of capital markets}

The benefits of having a corporate financial strategy are closely linked to the degree of capital market integration. Firms that are based in a country with a segmented and thin capital market have a lot to gain from breaking out of its domestic capital, thus being able to reap the benefit of a global cost of capital. Firms, facing a perfectly integrated financial market, should consequently not spend too much effort on cross-border financial issues. It can then be discussed how to measure the degree of international financial integration and how to act in accordance with this assessment. The overall financial integration encompasses all the financial market segments (money, bond and equity), but the measurement process boils in all cases down to a "law of one price" process (Oxelheim, 1990; Yeyati, Schmukler and Van Horen 2009). Below we discuss the equity market integration.

Over the last decades a significant volume of research has focused on ways of measuring equity market integration from an econometric point of view. Various schools of thought have developed, but for most of them the point of departure has been much the same: the law of one price, which states that if two or more markets are integrated, then identical securities should be priced identically in all of them. The controversial issue dividing the different schools concerns what "being priced identically" actually means.

One strand in the literature, which highlights identical movements, is based on the analysis of co-movements of equity-market returns. For the analysis of correlation of returns 
- prominent research is done by; Ahn and Kudo, 2011; Lau and Diltz, 1994; Lin, Engle and Ito 1994; for correlation of hourly returns, see Susmel and Engle, 1994; for stability over longer periods, see Erb, Harvey and Viskanta, 1994; Ibrahimi, Oxelheim and Wihlborg, 1995; Longin and Solnik, 1995; and for stability around the Black Monday or Crash of 1987, see for example King, Santana and Whadmani, 1994. For the recent turmoil around the post2008 finacial crisis, see Muna and Brooks (2012). Furthermore, Solnik (1996) provides an overview of correlations between industrialized markets and concludes that whereas measuring co-movements in equity-market returns in isolation leads to conclusions in terms of weak integration, measures of strong integration also involve the analysis of return gaps between equity-markets.

As the other major strand of literature many schools of thought in the area of finance assume strong financial market integration - i.e. start from the law of one price, but then after risks have been taken into account. In studies adopting this more stringent definition of integration the thrust of the analysis can vary. For example, from the role of currency risk (see e.g. Jorion, 1985), long-term differences in risk- adjusted returns (see e.g. Ibbotson, Siegel and Love, 1985), optimal international asset allocation (see e.g. Glen and Jorion 1993; Odier and Solnik, 1993), international asset pricing with extended CAPM (see e.g. Graham and Nikkinen, 2011; Hietala, 1989), home country preference bias (see e.g. French and Poterba, 1991; Cooper and Kaplanis, 1994; Tesar and Werner, 1995), the international pricing of risks (see e.g. Harvey, 1991; Dumas, 1994), international asset pricing with extended APT (see. e.g. Bansal, Hsieh and Viswanathan, 1993), and finally international asset pricing with consumption-based models (see e.g. Wheatley, 1988).

Taken together all these studies point in the same direction: towards increasing equity market integration. But when it comes to the degree of integration, the results are often inconclusive, even in the case of comparable markets and periods. This claim is supported by 
Naranjo and Protopapadakis (1997), who provide an overview of integration test results. The authors argue that the conflicting results may be partly due to the lack of an economic benchmark of integration with which the statistical tests can be compared. Oxelheim (2001) argues that the inconclusive results as regards to the degree of completeness of equity market integration reflects the composition of the stock market indices used and how they mirror a two-tier integration, i.e., the polarization of firms with global recognition and those without.

Fulfillment of the various prerequisites marks out different stages on the way towards perfect financial market integration (Oxelheim, 2001). The first prerequisite is the absence of capital controls that effectively prevent cross-border equity transactions - issues and trade. The second prerequisite concerns the efficiency of internal regulations and the absence of tax wedges and prohibitive transaction costs. The third prerequisite concerns the exchange of information and the absence of cross-border information asymmetries, including differences between corporate governance systems and information costs.

The process of integration as comprised by the fulfillment of these three prerequisites reflects activities of three major stakeholder groups: politicians with their dual function of trying to retain control over capital flows on the one hand and achieving a sound and safe financial infrastructure on the other; investors searching for profit opportunities; and managers trying to internationalize the cost of capital while maintaining control.

Historically, there has been considerable theoretical and empirical research on the segmentation of international capital markets. However, few studies have addressed the specific managerial challenges that internationalization of capital implies. The research issue of this chapter is to focus on the way individual companies can undertake actions to improve their market valuations, and thus their cost of capital. The key ingredients are the linkages between business strategy, firm motivation, and various financial strategies to reduce the corporate cost of capital. 


\section{Why Financial Strategy Matters}

There is a widespread misperception that financial strategy does not add value to the firm. This line of reasoning goes back to the research of two Nobel Prize economists, Modigliani and Miller. The implication of this view is basically that finance is irrelevant to corporate success. However, this argument ignores many facts like that all capital markets are not alike and information is not evenly distributed across nations. Even for highly liquid and well functioning capital markets, such as the one in the United States, a study of 750 companies reveals that better disclosure boosts stock price (Lang \& Lundholm, 1996). If there is no value creation in pursuing specific financial strategies, then companies ought considering to lay off their highly paid investor relations executives to enhance their stock price. On the contrary, we suggest that most markets are not fully financially integrated providing companies from these countries a reason to invest in more in financial strategies and investor relations than their peers in other markets in order to escape a mispriced and/or illiquid domestic stock market. The need for an active investor relations function is also shown by the fact that global investors strongly favor more visible (and larger) firms when investing in small equity markets (Dahlquist and Robertsson, 2001).

\section{Barriers to an international cost of capital}

We argue that corporate competitiveness is enhanced when a firm's dependence on an illiquid or partially segmented capital market is reduced. Financial market segmentation implies that a firm from one country faces higher financial costs than an exact similar company from another country. Research points to five major avenues to get an international cost of capital and increased competitiveness. The first route to internationalize the cost of capital is to list 
the company's shares on one or more foreign stock exchanges and the second route is to float equity issues to investors in one or more foreign countries. These two routes encompass in fact many different levels of ambition as is highlighted in Figure 1. The safest alternative for the inexperienced firm is to follow all the steps of the staircase starting with listing bonds at a less prestigious market. The boldest firm, however, go straight to the last step at once, even without a prior listing in their financial home market. This last-mentioned alternative has been adopted by many high-tech Israeli firms finding the home market too small to digest the risks of the firm. The listing enhances liquidity of shares, and for the availability of new capital a float of an equity issue is necessary. A third route to internationalizing the cost of capital is via a strategic alliance. Foreign industrial investors can overcome a segmented capital market by infusing equity into a target partner. A forth route to internationalize the cost of capital is to import a harsher governance regime on the board of the firm by recruiting a board member from the country of that regime (Oxelheim and Randøy, 2003). Finally, the fifth avenue - for which the lasting impact can be debated - is to get a lower cost of capital by attracting support from central and local government agencies (Oxelheim and Ghauri, 2009).

\section{INSERT FIGURE 1 ABOUT HERE}

In the 1980s and beginning of the 1990s one major venue for companies to escape a "thin", inefficient and heavily regulated domestic market was to place an equity issue on a foreign "prestigious" capital market. As previously stressed the internationalization of the cost of capital was a process with three stakeholders: investors, regulators, and managers. Investors are characterized by an endless search for new profit opportunities and portfolio risk reduction. On the other hand regulators pursue policies that are aimed at insulating the domestic market from the global one, and managers strive to eliminate disadvantages by 
trying to circumvent barriers and restrictions imposed by regulators. A successful stock issue should render the company benefits from a higher price/earnings ratio, or price to book ratio, abroad as compared to the one at home.

Corporate managers of firms resident in segmented equity markets will be rewarded for financial strategies that overcome the causes of capital market segmentation. These causes are as follows:

* Asymmetric information available to investors resident in different countries. This includes not only financial data on corporations but also the analytic methods used to evaluate the validity of a security's price.

* Different tax regulations, especially with regard to the treatment of capital gains and the double taxation of dividends.

* Regulation of securities markets.

* Alternative sets of optimal portfolios from the perspective of investors resident in one equity market compared to investors resident in other equity markets.

* Different agency costs for firms located in bank-dominated markets compared to firms located in the Anglo-American markets.

* Different levels of financial risk tolerance, such as debt ratios, in different countries.

* Differences in perceived foreign exchange risk, especially with respect to operating and transaction exposures.

* Takeover defenses that differ widely between the Anglo-American markets, characterized by one-share-one vote norms, and other markets featuring dual classes of stock and other takeover barriers.

* The level of transaction costs involved in purchasing, selling, and trading securities.

* Political risk such as unpredictable government interference in capital markets and arbitrary changes in rules.

The relative importance of each of these barriers changes over time and across countries and produce the overall degree of international financial integration of a given country. Moreover, when it comes to the financial strategy of a given firm it is also a question 
of firms' ability to benefit from market imperfections. However, it is hard to find consistent, i.e., across companies, evidence on how successful firms have been in exploiting these market imperfections. At the corporate level success is not only a matter of identification of misalignments in macro market prices but also a matter of the perceived ability of financial managers to exploit them (Oxelheim, Thorsheim and Wihlborg, 2011). In this chapter we use cases to illustrate the variety of corporate strategies employed to internationalize firms' cost of capital, as they evolved over time and across countries.

\section{The Path to Internationalization of Capital}

Let us in this section go deeper into the different financial strategies. Figure 1 shows how foreign equity markets are normally tapped using one or a combination of two financial strategies. The preparation and a first strategy consists of the cross-listing of the company's shares. The second strategy is then to make a directed issue of stocks, straight bonds, convertible bonds, or a hybrid instrument, sold in a specific foreign equity market. A directed private placement is also feasible. The broadening of the second strategy is to make a Euroequity issue sold in several equity markets simultaneously. This usually includes the home market in addition to foreign markets. In addition to the two strategies highlighted in Figure 1, a third related strategy is to receive an equity injection from a foreign partner as part of a strategic alliance.

Because of transaction and information acquisition barriers in the international capital market, a firm typically starts to raise funds in the domestic financial market. The information barriers are commonly larger for equity issues than for bond issues. Ideally, firms would like to jump from the domestic capital market to a "Euro-equity issue." This is usually impossible because the international investment community does not know the average firm. 
The normal path of internationalizing a firm's capital is to start with an international bond issue in a less prestigious market. This provides the firm with added experience and enhanced visibility (and scrutiny) in the financial market. If possible, it is desirable to skip this first step and go directly to the next steps, international bond issue in a liquid target market or a Eurobond issue sold in several markets. Raising equity requires more commitment to disclosure and investor relations. A firm could start by listing and selling equity in a less prestigious market, i.e. not the United States or the United Kingdom. This is even more costly in time and money than a bond issue, but still commonly less costly than a full-scale listing and equity issue in the United States or the United Kingdom.

The ultimate financial strategy - particular for large firms - is to have a Euro-equity issue sold simultaneously in both foreign equity markets and the domestic market. Within the Nordic area Electrolux (1986) was among the first to tap the Euro-equity market. Euro-equity issue is also the path being taken by some of privatized firms, such as Tele-Danmark in 1994.

\section{Cross-listings}

Firms cross-list on foreign stock exchanges for a variety of reasons whether or not they actually sell equity issues abroad (e.g. Modén and Oxelheim, 1997; Karolyi, 1998; and for an overview see Pagano and Röell, 2007). The main documented motives are as follows.

* Achieve a world pricing of its equity when the home market is segmented.

* Improve the international visibility of the firm's products and securities to its customers, suppliers, creditors and host governments.

* Make it easier for the firm's foreign stockholders to trade its shares in their home markets and currencies, thus increasing the stock's overall liquidity.

* Foreign underwriters insist on local listing in their markets to help market a new equity issue. 
* Create a liquid secondary market for shares used to acquire foreign firms, or to distribute to employees of foreign subsidiaries.

* Comply with governmental requirements for financing foreign investments.

The extent to which a firm's stock price can be increased by merely cross-listing on a foreign stock exchange, without a simultaneous equity issue, depends on how severely the home market is segmented and what efforts the firm has made to attract international investors. Sundaram and Logue (1996) found a favorable effect on stock prices for foreign firms that cross-listed on the New York and American Stock Exchanges during 1982-1992. However, Modén and Oxelheim (1997) report that a simultaneous equity issue and crosslisting on the New York and American Stock Exchanges by Swedish firms generates a higher shareholder value than a mere cross-listing because of the stronger commitment by the issuing firm it signals.

Foreign investors can acquire a firm's stock through transactions on foreign stock exchanges. By cross-listing on their home stock market, a firm can help those investors to trade shares and receive dividends in their home currency. The hope is to increase overall liquidity for trading the firm's shares and to encourage the foreign investors to hold the firm's shares rather than selling them back to the firm's home market.

\section{Directed Stock Issue}

A directed stock issue is defined as one targeted at investors in a single country and underwritten in whole or in part by investment institutions from that country. The issue might or might not be listed on a stock exchange in the target market.

Directed stock issues were the investment of choice for Nordic firms in the 1980s and early 1990s. Segmentation of the home equity markets made it difficult to attract international investors with a "shotgun" approach. Indeed, the early Nordic equity issues abroad were 
focused and heavily promoted by Goldman, Sachs and Company (Novo Industri A/S), and Morgan Stanley (L.M. Ericsson AB, Fortia AB/Pharmacia, and Gambro).

Directed stock issues have been particularly useful to Nordic firms desiring to improve the liquidity of their shares, to achieve international pricing of their shares, and to become more visible to customers and suppliers. Even after the Nordic equity markets became less segmented, directed stock issues have been useful to fund acquisitions or new capital investments in the targeted foreign market. This was the motivation for Norwegian-based Hafslund Nycomed's directed share issues in London (1989) and the United States (1992), as well as its listing on the New York Stock Exchange (1992).

At the end of the 1990s the pattern of directed issues turned from having been more or less $100 \%$ cash issues into more or less $100 \%$ non-cash issues. All growth firms used their own shares to pay for acquisitions (Oxelheim, 2001). However, this pattern did not at all reduce the burden on management of having a successful financial strategy.

\section{Euro-equity Issues}

Not only have Nordic equity markets become less segmented but this trend is happening worldwide. This occurred simultaneously with a rapid increase in international portfolio investment over the last twenty five years. As a result, a robust Euro-equity market has evolved starting in the mid-1980s.

Firms are able to issue equity, which is underwritten and distributed in more than one foreign equity market, sometimes simultaneously with distribution in the home market. The same financial institutions that form the backbone of the Eurobond market are the main players in the newer Euro-equity market.

The Euro-equity market has been the main vehicle for privatizing large public utilities from both industrialized and emerging markets. Nordic privatizations have in the recent past 
made use of the Euro-equity market and are expected to do more of the same in the future. Notable examples are the privatization of Tele Danmark (1994), Telia of Sweden (2000), and Telenor of Norway (2000). It should be noted that this capital market only developed during the past decade, so earlier Nordic equity issues did not really have a choice to use it.

Simultaneous distribution in several equity markets implies a single worldwide price. This price is often somewhat different than the previous home market price but results from a compromise among the various national underwriters.

\section{Strategic Alliances}

Strategic alliances are usually created to take advantage of synergies in joint marketing, product development, or other commercial activities. However, financial synergy may also arise if a financially strong firm helps a financially weak partner by injecting favorably priced equity or debt into it.

The equity-based strategic alliances have in most cases helped the receiving firm to boost its stock price. However, in most cases the alliance relationship has been a "trial marriage". After some years the strategic alliance typically ends with either a merger/acquisition (as with Elektrisk Bureau). The strategic alliance between Huhtamaki and Procordia was finished after three years. However, Elektrisk Bureau A/S and ASEA AB ended as a merger after five years.

The key to financial synergy with respect to equity pricing is that portfolio investors price shares according to their expected risk-adjusted rate of return. This is necessarily somewhat biased by past performance, but in any case cannot usually anticipate the synergistic effects of a strategic alliance that does not yet exist. Thus, the value of equity in Bang \& Olufsen was higher from the perspective of Philips NV, which anticipated the operating and financial synergies, than Bang \& Olufsen's value to the existing market of 
portfolio investors. Bang \& Olufsen realized many of the anticipated synergies. Its operating performance improved dramatically. It also enjoyed a hefty share price increase compared to the Danish market as a whole. In 1997 it was able to repurchase its shares that were held by Philips NV but continued most other aspects of the strategic alliance.

\section{Internationalization of Corporate Governance}

The globalization of ownership creates an opportunity for foreign shareholders to buy large stakes in the firm. However, the investors must have confidence that the capital they provide will be properly monitored. For small shareholders the cost of getting involved may be prohibitive. But larger shareholders can afford active monitoring, for instance through foreign board membership (Shleifer and Vishny, 1986, 2007). Board representatives for large foreign shareholders are presumably "outsiders" who will not use their influence as board members to obtain benefits that do not accrue to other shareholders (see, e.g., Stulz, 1999). As they are more likely to perform the arm's-length monitoring, their entry as owners should increase the value of the firm.

Compliance with the stricter information and monitoring requirements of a more demanding corporate governance system can substantially increase a firm's costs. However, this also discourages managers from extracting private benefits, and it therefore strengthens the firm's commitment to protecting the interests of minority shareholders (Reese and Weisback, 2001). Foreign listing - or the undertaking of foreign equity issues - is a costly affair for the firm, both in terms of outright expenses and in terms of top management involvement (Oxelheim et. al. 1998; Blass and Yafeh, 2001).

Many firms might ex ante consider a foreign listing too costly. For these firms, however, there is a way of achieving a global cost of capital at a lower outright cost. In exercising this option a firm signals its willingness to improve the monitoring opportunities 
by including foreign outsider members on the board. This alternative of "importing" a more demanding corporate governance system by having one or more representatives of that system as board members signals a higher commitment to corporate monitoring and transparency. Oxelheim and Randøy (2003) suggest that the presence of at least one foreign outsider member representing a more demanding system, i.e. the Anglo-American system, will result in more active boards that are more independent of management. The key ingredient of this alternative is the bridging of the previously mentioned cross-border information gap, and an improvement in corporate governance - in which value can be created through access to new investors. New and/or improved access to a foreign investor clientele should entail a higher share price, and thus a lower cost of capital (Oxelheim et al. 1998; Bekaert and Harvey, 2000).

Most past corporate governance studies have presumed implicitly that a company is embedded in the corporate governance model of its home country (e.g., La Porta et al., 1998, La Porta, Lopez-de-Silanes and Vishny, 1999), unless the firm is a subsidiary of a foreign company. An examination of the impact of outsider foreign board membership needs to consider three different board mandates. One alternative is that the board member has a mandate to represent an owner with a major commercial or long-lasting interest in the firm such as a foreign direct investment (FDI) or a subsidiary. A second alternative is that the board member represents a foreign owner with a big portfolio stake in the firm. Finally, the board member may be an independent outsider chosen by the company specifically to signal its willingness to comply with another corporate governance system. The choice is assumed here to be independent of ownership structure. By having at least one foreign board member in this third category and representing the Anglo-American system, the firm is signaling its willingness to be monitored by the rules of a more demanding corporate governance system. 
The strongest consistent signal of commitment is assumed to emerge from a combination of a cross-listing on the Anglo-American markets and the inclusion of at least one independently chosen outsider foreign board member representing the Anglo-American corporate governance system. Both these features indicate an improvement in monitoring and an increase in transparency, which is valued by investors (Oxelheim and Randöy, 2003). Hence, a forth strategy and a low-cost alternative to foreign listing and equity issues is to add one or more independent directors from a prestigious capital market to the corporate board of directors (Randøy and Oxelheim, 2003). This might improve corporate governance of the firm, and help it to build confidence with foreign investors. Hence, given the substantial increases in costs related to foreign listings - particularly in the U.S. - a viable alternative to a foreign listing might be internationalization of the corporate boards and internationalization of the incentives system for top executives. Tthe undertaking of an international cross-listing should not, on its own, be regarded as a completed mission.

\section{Finance-specific advantages and foreign investment}

In efficient and internationally integrated financial markets, no firm has a financial advantage over another, since all firms have equal access to finance at equal (risk-adjusted) cost. Arguing for a finance-advantage effect thus requires an assumption of imperfect capital markets that are at least partially internationally segmented. While the theories underpinning Dunnings' (e.g. 1993) eclectic OLI paradigm (especially internalization theory) largely build on imperfections in goods markets, the effects of financial market imperfections have received less attention.

In a conceptual paper, Oxelheim, Randøy, and Stonehill (2001) argue that a firm's financial characteristics are not merely by-products of its competitive strength but constitute a distinct set of explanatory variables. By having a superior financial strategy a firm is able to 
minimize its cost and maximize its availability of capital relative to its competitors, both domestic and foreign. By lowering the discount factor of any investment, such a financial advantage increases the firm's likelihood of engaging in profitable foreign direct invesments (FDIs). Forssbæck and Oxelheim (2008) brings this argument to the data. As their point of departure, they focus on the ownership-location-internalization (OLI) framework (Dunning, 1993) since, in its ambition of being all inclusive, it provides a list of "standard" FDI determinants against which they test against the added explanatory value from including financial factors. They thus construct a number of firm-level financial characteristics ranging from simple cost of capital and creditworthiness measures to outright financial strategies such as listing the firm's equity on large and competitive foreign stock exchanges. The results, based on a sample of 1379 European non-financial firms' cross-border acquisitions in a total of 44 target markets, show a strongly significant explanatory power of a number of financial characteristics and of financial strategies undertaken in a period of up to 60 months prior to the investment. These results give a clear indication of the important role played by financespecific factors and support the notion that firms can create ownership advantages by adopting strategies to improve their financial strength (in Forssbaeck and Oxelheim, 2011, they find support for this also in a general model).

In the race for inward FDI, history reveals that governments are interested in attracting knowledge intense firms by different means altering in the last minute the OLI-pattern to their own advantage. The high unemployment rate in most countries following from the financial crisis of 2008 and onwards made many government inclined to use non-transparent measures like subisides, loan and equity on non-market conditions and warranties to convince firms to establish themselves in their country in order for governemts to signal power by creating jobs. This way they contribute artificially to lower the cost of capital of the targetted firm (Oxelheim and Ghauri, 2009). 


\section{De-listing}

International financial integration is a recurrent phenomenon in history. Financial integration was in the pre WW1-period close to perfect and allowed most firms access to global capital markets. In the Nordic region - as shown in Oxelheim (2001) - GN Store Nord from Denmark was early out and listed in London already 1869. The Danish bank - Privatbanken (now Unibank) - listed in Amsterdam 1899. Norsk Hydro was listed in Geneva and Paris 1909. Even in between the two World Wars the financial markets were open to cross border financial operations. The Swedish company Alfa Laval was listed at three exchanges in 1928 (London, Geneva and Amsterdam). Other Swedish companies cross-listing in that period were Electrolux (London, 1928), SKF (London, 1928, Paris, 1929 and Geneva, 1935) and Swedish Match (today famous for snuff).The latter company stands out for its multi-market listing. It was listed at 10 European markets between 1922 and 1930. The special feature is that the company was listed at as many as five markets in Switzerland (Basel, Bern, Geneva, Lausanne and Zürich). The pattern in the 2010s goes in the opposite direction. Once the firm has reached the top of the ladder in Figure 1 and received a global recognition and a global cost of capital the firm starts cutting down its listing at multiple markets. The delisting will reduce outright costs and further boost the de-listed firm's cost of capital - something that in the last two decades have been made possible by the development of information technologies.

\section{Towards a Global Cost of Capital}

Why is a lower cost of capital such an important issue for an aspiring global firm? We identify three major reasons why international managers should be concerned. First, in an increasingly integrated world of competitive and open product markets, producers have difficulties in 
passing on a potentially higher cost of capital to customers. Nokia of Finland - the number one cellular phone maker in the world (as of late 2010) - does not have a "cozy" home market where it can enjoy premium prices. Second, the advent of the knowledge economy makes equity financing more important, as the knowledge intensive firms do not make the kind of investments that produce collateral for debt financing. Third, the global wave of mergers and acquisitions makes it important for companies to boost stock prices in order to maintain influence after a potential merger and protect themselves from being taken over.

The globalization of ownership, and thus internationalizing the cost of capital, leads to the new global shareholder regime (Table 1). A successful internationalization of capital produces a very international ownership structure, as the firm becomes a necessary part of global investors' world portfolio. Just two years after Nokia of Finland was listed on the NYSE in 1994, as much as $61 \%$ of its shareholders were resident outside the home country. This increased further as Nokia succeeded and actually was about $86 \%$ in early 2010 .

\section{Lack of transparency means higher cost of capital}

While the meaning of "transparency" can vary from one situation to another, the common denominator is that a lack of transparency creates some form of information asymmetry (Oxelheim, 2006). In the political context, this asymmetry often means a difficulty in understanding current policy and uncertainty as to what the next step may be. In relation to a specific business - greater transparency helps to bridge the information gap between the firm and its investors/potential investors. The price for this lack of transparency appears in the form of a risk premium for ambiguity and opaguness at the firm leve - and as higher cost of capital. Hence, a good financial strategy encompasses the disclosure of relevant information in order to and achieve "optimal” transparency (Oxelheim, 2010). 
The link between financial and overall corporate strategies

As summarized in Table 1, shareholder value is the paramount measure of corporate success within the global shareholder regime. As stock ownership becomes increasingly international, the demands for accurate and timely information increases, and shareholders are showing less tolerance for meager performance. In order to build shareholder interest this research suggests that companies need to have an active investor relations function. Building confidence with international institutional investors should be the main focus of this activity, and case stories like Nokia show how this has been successful in the past (Oxelheim et al 1998).

Table 1: The Effect of a Global Cost of Capital: The Global Shareholder Regime

\section{Effect on Shareholders and Governing Structure}

- Potentially higher stock price: increased shareholder returns

- More demanding shareholders and less "loyal" if a company does not satisfy expectations.

- Top management and investor relations need to focus on international institutional investors

- Need to strengthen the corporate board and add more independent directors

- Need to redesign incentive packages for key personnel based on shareholder value.

\section{Effect on Business Strategy}

- Need to focus business strategy on core competencies and disposal of non-core business lines.

- Need to be able to attract large amount of funds: strategic flexibility

- The firm is more exposed to takeovers (taking down take-over defenses)

- Need to make the firm attractive as a partner for mergers

A company with global ambitions needs to focus on corporate governance in order to gain shareholder confidence. One possible firm response could be to strengthen the governing board by recruiting a larger number of outside directors. Oxelheim, Gregoric, Randøy and Thomsen (2011) highlight how it is mostly financial globalization that drives the internationalization of boards. Moreover, the NASDAQ Stock Exchange requires that a company that seeks listing have a majority of independent (outside) directors (NASDAQ, 
2010). Furthermore, global investors expect that top management compensation be linked to the creation of shareholder value.

Furthermore, we argue that the financial strategy of gaining "membership" of a global shareholder regime affects the business strategy of the firm. In the "old world order" finance played a secondary role to business strategy, not so any more. Unless the company focuses on its core competence and disposes non-core activities, the company can be exposed to a hostile takeover attempt. Long-term confidence needs to be built with major institutional investors, such that a large amount of funds can be accessed if necessary (typically in relation to an acquisition). A company can strengthen its strategic flexibility and thus provide strategic real options by building trust with large investors. Within the global shareholder regime companies with an active defense against takeovers are penalized. For example, within the Nordic economies non-voting shares have become rather unattractive to investors. The cost of various takeover defenses can be measured in terms of lower stock price and thus a higher cost of capital. This provides closely controlled companies with a strong incentive for a more transparent shareholder policy. In fact, making the company an attractive partner of a potential merger becomes an important route to higher shareholder return.

\section{Concluding remarks}

In this chapter we have shown ways for aspiring global companies to achieve an international cost of capital. We have illustrated our theoretical arguments by referring to some relevant case studies. These cases show how access to competitively priced capital accelerated the international growth prospects of companies from small and thin capital markets at the end of the $20^{\text {th }}$ century. In fact, without this funding the competitiveness of these firms would have been significantly hampered. We claim that the our cases form the Nordic market provide an excellent "laboratory" to understand successful execution of a global financial strategy and its 
implication for overall corporate strategy. At the beginning of the 2010s this is particularly appropriate for any small- to medium-sized firm, as well as larger firms from more segmented capital markets in emerging economies.

We argue that the corporate motivation for internationalizing the cost of capital is the starting point for understanding a firm's globalization of ownership. Globalization of capital is particularly appropriate in conjunction with globalization on the product side. Second, we emphasize the need to link the business strategy with the financial strategy. Several avenues to internationalizing the cost of capital exist; such as international cross-listing, foreign stock issues, strategic equity alliances, internationalization of corporate governance and receiving support from governments. We argue that globalization of capital is more advantageous to companies with unique products/services and/or unique resources that serve high-growth markets.

The internationalization of ownership calls for a new shareholder regime. First of all the internationalization affects shareholders and governing of firms, as global capital tends to be less tolerant of meager performance. Second, this implies that executives need to focus on the core competencies of the firm, as investors do not approve value-destroying diversification. Furthermore, global ownership also provides executives with greater opportunities to finance high-return/high-risk projects.

For the home country of aspiring global firms, internationalization of capital provides both opportunities and threats. On the positive side internationalization of capital allows small country to produce some impressive global companies, such as Novo of Denmark, Nokia of Finland and Ericsson of Sweden. On the other side, global firms are becoming more "foot loose" and without the right government policies (or other factors beyond the control of governments) companies will move abroad. 


\section{References}

Ahn, E and F. Kudo, 2011, Transmission of Returns between the U.S. stock market and four other major international stock market indexes. Journal of Economics and International Finance 3(7): 468474

Bansal, R., Hsieh, D. and R. Viswanathan, 1993, A New Approach to International Arbitrage Pricing. Journal of Finance 48: 1231- 1262.

Bekaert, G. and C.R Harvey, 2000, Foreign speculators and emerging equity markets. Journal of Finance, 55: 565-613.

Blass, A. and Y. Yafeh, 2001, Vagabond shoes longing to stay: Why foreign firms list in the United States. Journal of Banking and Finance 25: 555-572.

Coffee, J. C. Jr2002, Racing Towards the Top? The Impact of Cross-Listings and Stock Market Competition on International Corporate Governance. Columbia Law Review 102: 1757-1831.

Cooper, I. and E. Kaplanis, 1994, Home Bias in Equity Portfolios, Inflation Hedging and International Capital Market Equilibrium. Review of Financial Studies 7: 45-60.

Dahlquist, M. and G. Robertsson, 2001, Direct foreign ownership, institutional investors, and firm characteristics. Journal of Financial Economics, 59: 413-440.

Doidge, C., G. Karolyi and R. Stulz,2004, Why are foreign firms listed in the U.S. worth more?. Journal of Financial Economics, 71: 205-238.

Dumas, B., 1994, Partial Equilibrium versus General Equilibrium Models of the International Capital Market in: F. van der Ploeg (ed.), The Handbook of International Macroeconomics, Blackwell, (Cambridge, MA).

Dunning, J. H. 1993, Multinational Enterprises in the Global Economy. Addison-Wesley ( Wokingham).

Erb, C.B., C.R. Harvey and T.E. Viskanta, 1994, Forecasting International Equity Correlations. Financial Analysts Journal 50: 32-45.

Forssbaeck, J. and L. Oxelheim 2008, Finance-specific Factors as Drivers of Cross-border Investment - An Empirical Investigation. International Business Review, 17 ( 6): 630-641.

Forssbaeck, J. and L. Oxelheim 2011, Corporate Financial Determinants of Foreign Direct Investment. Quarterly Review of Economics and Finance, 51, 269-282.

French,K. and J. Poterba, 1991, Investor Diversification and International Equity Markets, American Economic Review, Papers and proceedings of the 103 annual meeting of AEA, 222-226.

Glen, J. and P. Jorion, 1993, Currency Hedging for International Portfolios. Journal of Finance 48: $1865-1886$.

Graham, M and J, Nikkinen, 2012. Co-movement of the Finnish and international stock markets: a wavelet analysis. European Journal of Finance, forthcoming

DOI: $10.1080 / 1351847 X .2010 .543839$ 
Haanes, K. and Ø, Fjeldstad, 2000, Linking intangible resources and competition. European Management Journal 18: 52-62.

Harvey, C., 1991, The world price of covariance risk, Journal of Finance 46: 111-157.

Hearn, B., Piesse,J., \& Strange,R.(2010) Market liquidity and stock size premia in emerging financial markets:The implications for foreign investment. International Business Review, 19 (5): 489-501.

Hietala, P.T., 1989, Asset Pricing in Partially Segmented Markets: Evidence from the Finnish Market. Journal of Finance 44: 697-718.

Ibbotson, R., Siegel, L. and K. Love, 1985, World Wealth: Market Values and Returns., Journal of Portfolio Management 11: 4-23.

Ibrahimi, I., Oxelheim, L. and C. Wihlborg, 1995, Macroeconomic Fluctuations and International Stock Markets, in: Aggarwal, R. and D.Schirm (eds.), Global Portfolio Diversification (Academic Press, New York)

Jorion, P., 1985, International Portfolio Diversification with Estimation Risk. Journal of Business 58: 259-278.

Kaplanis, E., 1988, Stability and Forecasting of the Co-movement of Measures of International Stock Market Returns. Journal of International Money and Finance 7: 63-75.

Karolyi, A.C. 1998, Why do companies list shares abroad? A survey of the Evidence and its Managerial Implications. Financial Markets, Institutions \& Instruments, 7: 1-59

Kay, J.A. 1997, The Business of Economics. Oxford University Press ( Oxford).

King, M, Santana, E. and S. Whadwani, 1994, Volatility and Links between National Stock Markets. Econometrica 62: 901-933.

Lang, M.H. and R. J. Lundholm, 1996, Corporate Disclosure Policy and Analyst Behavior. Accounting Review, 71, 467-492.

La Porta, R., Lopez-de-Silanes, F.,and A. Shleifer, 1999, Corporate ownership around the world. Journal of Finance 54: 471-517.

La Porta, R., Lopez-de-Silanes, F., Shleifer, A., and R. Vishny, 1998, Law and finance. Journal of Political Economy 106: 1113-1155.

Lau, S.T. and J.D. Diltz, 1994, Stock Returns and the Transfer of Information between the New York and Tokyo Stock Exchanges, Journal of International Money and Finance 13: 211222.

Lin, W.L., Engle, R.F. and T. Ito, 1994, Do Bulls and Bears Move across Borders?International Transmission of Stock Returns and Volatility, Review of Financial Studies 7: 507-538.

Longin, F. and B. Solnik, 1995, Is the International Correlation of Equity Returns Constant: 1960-1990?. Journal of International Money and Finance 14: 3-26.

Mittoo, U. and Z. Zhang. 2008, The capital structure of multinational corporations: Canadian versus U.S. evidence. Journal of Corporate Finance 14, (5): 706-720. 
Modén, K.-M. and L. Oxelheim, 1997, Why issue equity abroad? -Corporate Efforts and Stock Market Responses. Management International Review, 37: 223-241.

Muna, M. and R. Brooks (2012). The roles of news and volatility in stock market correlations during the global financial crisis. Emerging Market Review, forthcoming, doi:10.1016/j.ememar.2011.09.001

Naranjo, A. and A. Protopapadakis, 1997, Financial market integration tests: an investigation using US equity markets. Journal of International Financial Markets, Institutions \& Money 7: 93-135.

NASDAQ 2010, Listing Requirements \& Fees. http://www.nasdaq.com/about/nasdaq_listing_req_fees.pdf

Odier, P. and B. Solnik, 1993, Lessons for International Asset Allocation. Financial Analysts Journal 49: 63-77.

O'Connor, T. 2011. Financial Development, Internationalisation and Firm Value. Journal of Emerging Market Finance 10: 21-71.

Oxelheim, L. 1990, International Financial Integration, Springer Verlag (Berlin)

Oxelheim, L. 1996, Financial Markets in Transition - Globalization, Investment and Economic Growth.: Routledge (London and New York).

Oxelheim, L. 2001, Routes to Equity Market Integration - the Iinterplay between Politicians, Investors and Managers. Journal of Multinational Financial Management, 11: 183-211.

Oxelheim, L. 2006, Corporate and Institutional Transparency for Economic Growth in Europe, Elsevier (Oxford).

Oxelheim, L., Randøy, T. and A. Stonehill, 2001, On the Treatment of Finance-Specific Factors Within the OLI Paradigm. International Business Review 10: 381-298.

Oxelheim, L., Stonehill, A, Randøy, T., Vikkula, K, Dullum K.B. and K-M. Modén, 1998,Corporate Strategies to Internationalize the Cost of Capital, Handelshøjskolens Forlag ( Copenhagen).

Oxelheim, L. and T. Randøy, 2003, The Impact of Foreign Membership on Firm Valuation. Journal of Banking and Finance 27: 2369-2392.

Oxelheim, L. and T. Randøy, 2005, The Anglo-American financial influence on CEO compensation in non-Anglo-American firms. Journal of International Business Studies, 36: 1-14.

Oxelheim, L., A. Gregoric, T. Randøy and S. Thomsen 2011,From Global Firms to Global Boards, Conference paper, Academy of International Business Annual Conference, Nagoya, June, 2011.

Pagano, M., Röell, A. and J. Zechner, 2002, The geography of Equity Listing: Why Do Companies List Abroad?. Journal of Finance, 57: 2651-2694.

Randøy, T., Oxelheim, L., and A. Stonehill, 2001, Corporate financial strategies for global competitiveness. European Management Journal, 19: 659-669. 
Reese, W. Jr., and M. Weisback, 2001, Protection of minority shareholder interests, cross-listings in the United States, and subsequent equity offerings. Working Paper \#8164, NBER.

Shleifer, A.,and R. Vishny, 1986, Large shareholders and corporate control. Journal of Political Economy 94: 461-488.

Shleifer, A., and R. Vishny, 1997, A survey of corporate governance. Journal of Finance 52: 737-783.

Solnik, B., 1996, International Investments, (Addison Wesley (Reading, MA).

Stulz, R.M. 1999,Globalization, corporate finance and the cost of capital. Journal of Applied Corporate Finance, 12: 8-25.

Stultz, R.M, 1981, A model of international asset pricing. Journal of Financial Economics 9: 383-406.

Sundaram, A.K. and D.E. Logue, 1996. Valuation effects of foreign company listings on U.S Exchanges. Journal of International Business, 27: 67-88.

Susmel, R. and R.F. Engle, 1994, Hourly Volatility Spillovers between International Equity Markets. Journal of International Money and Finance 13: 3-25.

Tesar, L. and I. Werner, 1995, Home Bias and High Turnover. Journal of International Money and Finance 14: 467-492.

Useem, M. 1998,Corporate leadership in a globalizing equity market. Academy of Management Executive. 12: 43-59.

Wheatley, S.,1988, Some tests on international equity integration. Journal of Financial Economics 21: 177-212.

Yeyati, E, S. Schmukler and N. Van Horen, 2009, International financial integration through the law of one price: The role of liquidity and capital controls. Journal of Financial Intermediation, 18 (3): 432-463. 
Figure 1 Major corporate strategies for eliminating cross-border information asymmetries in internationalizing the cost of capital

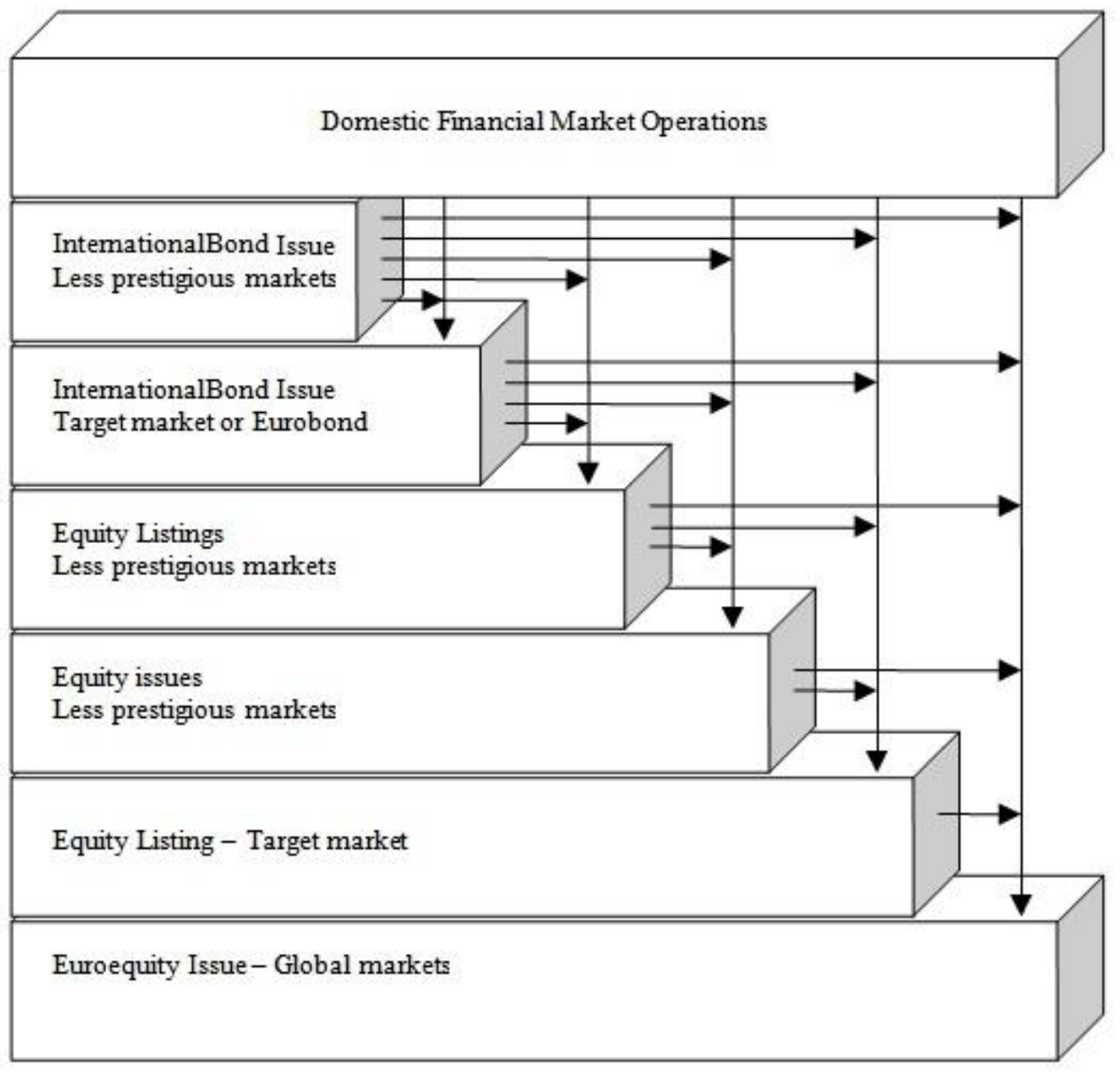

Source: Oxelheim (2001) 